\title{
The effect of Echinacea preparations in three laboratory tests of anxiety. Comparison with chlordiazepoxide
}

\begin{tabular}{|c|c|}
\hline Journal: & Phytotherapy Research \\
\hline Manuscript ID: & PTR-09-1128.R1 \\
\hline Wiley - Manuscript type: & Full Paper \\
\hline $\begin{array}{r}\text { Date Submitted by the } \\
\text { Author: }\end{array}$ & 22-Feb-2010 \\
\hline Complete List of Authors: & $\begin{array}{l}\text { Haller, Jozsef; Institute of Experimental Medicine } \\
\text { Hohmann, Judit; University of Szeged, Department of } \\
\text { Pharmacognosy, Faculty of Pharmacy } \\
\text { Freund, Tamas; Institute of Experimental Medicine }\end{array}$ \\
\hline Keyword: & $\begin{array}{l}\text { Echinacea, anxiety, rat, elevated plus-maze, social interaction, } \\
\text { stress-induced social avoidance }\end{array}$ \\
\hline
\end{tabular}

\section{(5) scholarONE" \\ Manuscript Central}




\section{COVER SHEET}

Title: The effect of Echinacea preparations in three laboratory tests of anxiety. Comparison with chlordiazepoxide

Authors: J. Haller ${ }^{1}$, J. Hohmann ${ }^{2}$, T.F. Freund ${ }^{1}$

Running head: Echinacea and anxiety

\section{Affiliation: \\ ${ }^{1}$ Institute of Experimental Medicine, Budapest, Hungary \\ ${ }^{2}$ Department of Pharmacognosy, Faculty of Pharmacy, University of Szeged, Hungary}

\section{Corresponding author}

Jozsef Haller, Ph.D., D.Sc.

Institute of Experimental Medicine

Department of Behavioral Neurobiology

1450 Budapest, P.O. Box 67

Hungary

Phone: +36 12109406

Fax: +36 12109951

E-mail: haller@koki.hu

\section{Acknowledgements}

This work was supported by the NKTH Jedlik Anyos grant to HJ and FTF. FTF and HJ are owners of Hungarian patent application No P0600489, PCT patent application No PCT/HU2007/000052, European patent application No EP 07733869.7, US patent application No. 12/304 558 and Hong Kong patent application 09109349.0 concerning the use of Echinacea preparations for the treatment of anxiety. The authors thank Cheryl Myers for her help in editing this manuscript. 


\begin{abstract}
Echinacea preparations are traditionally used to treat upper respiratory infections and inflammations. No psychotropic effects of Echinacea were reported so far, although some recently reported active constituents are behaviorally active. Prompted by these findings, we evaluated the anxiolytic potential of 5 different Echinacea preparations. Three of these decreased anxiety but two of them had a very narrow effective dose range. Only one extract decreased anxiety within a wide dose-range (3-8 mg/kg). Anxiolytic effects were consistently seen in three different tests of anxiety, the elevated plus-maze, social interaction and shockinduced social avoidance tests. No locomotor suppressant effects were seen at any dose. Noteworthy, the doses that showed anxiolytic effects in the present study were much lower than those used in the laboratory models of the traditional indications. Chlordiazepoxide robustly decreased anxiety-like behavior in all tests but suppressed locomotion at higher doses. Perceived and real risks of conventional medications increase the demand for alternative therapies, provided that these are safe and efficient. Earlier evidence shows that Echinacea preparations have an excellent safety profile, while our findings suggest for the first time that certain preparations have a considerable anxiolytic potential. Further research is required to identify factors that differentiate efficient and inefficient preparations.
\end{abstract}

Keywords: Echinacea, anxiety, rat, elevated plus-maze, social interaction, stressinduced social avoidance 


\section{Introduction}

Echinacea preparations have been used for centuries by Native Americans as antiinflammatory agents and for the treatment of upper respiratory infections; such treatments were incorporated into Western medicine about a century ago (Barnes et al., 2005; Birt et al., 2008; Blumenthal and Busse, 1998; Borchers et al., 2000). No psychotropic effects of Echinacea preparations have yet been elucidated, but recent studies identified active constituents by which these may affect behavior, especially anxiety-like behavior.

Echinacea preparations contain a large number of different alkamydes, the structures of which are very similar to that of the endocannabinoid anandamide (Bauer and Remiger, 1989; Wu et al., 2009). Certain alkamydes behave as cannabinomimetics at both the cannabinoid CB1 and CB2 receptor, and inhibit the anandamide-degrading enzyme fatty acid amid hydrolase (FAAH) (Woelkart et al., 2005). Although the interaction between cannabinoids and anxiety is complex (Witkin et al., 2005), CB1 signaling has been repeatedly implicated in the control of anxiety (Freund, 2003; Haller et al., 2002). Additionally, FAAH inhibition is considered a promising new anxiolytic drug target (Piomelli et al., 2006). Unidentified components of Echinacea extracts have been shown to be agonists at the transient receptor potential vanilloid-1 (TRPV1) receptors (Birt et al., 2008), a mechanism that has also been implicated in the control of anxiety (Starowicz et al., 2008). Certain Echinacea preparations contain rosmarinic acid, which has decreased anxiety in laboratory models at low doses (Biber et al., 2009; Pereira et al., 2005). In addition, caffeic acid is one of the major constituents of Echinacea; this compound decreases anxiety by indirectly modulating $\alpha_{1 \mathrm{~A}}$ adrenoceptors (Takeda et al., 2003). Also noteworthy is the fact that the above-listed constituents of Echinacea preparations readily cross the blood-brain barrier (Birt et al., 2008; Woelkart et al., 2009; Konishi et al., 2005). 
Some of the above-listed effects of Echinacea components are weak, and/or the brain concentrations after oral administration are too low to effectively modulate the mechanisms involved in anxiety control. For example, the Ki values of CB1 binding and the brain concentrations of alkamydes exclude robust effects of orally administered alkamydes on CB1 receptors (Woelkart et al., 2005, 2009). Yet, anandamide -the structure of which is very similar to that of alkamides- affects receptors other than the CB1, e.g. de PPAR $\alpha$ receptor (Mazzola et al., 2009). It is also worth noting that the TRPV1 agonist activity of Echinacea preparations is rather strong as it is produced at doses similar to those employed here (Birt et al., 2008). These considerations suggest that particular components of Echinacea preparations, alone or in combination with synergistic/additive effects, show great promise for anxiolytic drug development.

Prompted by the above findings, we started a series of studies to evaluate the anxiolytic potential of Echinacea preparations. It is noteworthy that, despite the extensive research on and wide use of this plant, no psychotropic effects have thus far been identified. We believe that this paucity of data is mainly due to two factors. First, the anxiolytic effect was detected at doses that were about one order of magnitude lower than those used for the traditional indications (see below). Secondly, only a fraction of Echinacea preparations showed consistent anxiolytic effects in our studies. In addition, the improvement of infectious diseases inherently improves mood, which may subjectively mask the intrinsic anxiolytic effects of the extracts that do show anxiolytic effects.

\section{Materials and Methods}

Animals

Subjects were 3-month-old male Wistar rats provided by Charles River Laboratories (Budapest, Hungary), and weighing 250-300 g. Rats were fed on standard laboratory food (Charles River Laboratories). Water was available ad libitum. Temperature and relative 
humidity were kept at $22 \pm 2{ }^{\circ} \mathrm{C}$ and $60 \pm 10 \%$, respectively. A light/dark cycle of $12 \mathrm{~h}$ was ensured with lights on at $0700 \mathrm{~h}$. All rats were housed in 1354G Eurostandard Type 4 cages $(59.5 \times 38 \times 22 \mathrm{~cm})$ in groups of four. Acclimatization to housing conditions lasted at least 1 week. All subjects were experimentally naive and used in only one experiment each (with no drug history prior to the experiment).

Experiments were carried out in accordance with the European Communities Council Directive of 24 November 1986 (86/609/EEC) and were reviewed and approved by the Animal Welfare Committee of the Institute of Experimental Medicine.

\section{Experimental design}

Experiment 1 evaluated the anxiolytic potential of Extract No. 1 in the elevated plusmaze test. This experiment was also used to establish effective dose-ranges; therefore, 7 doses were tested (vehicle, $0.5,1,1.5,2,3$, and $6 \mathrm{mg} / \mathrm{kg}$ ). Rats were submitted to the test 30 min after treatment. Sample size was 10 per treatment group.

Experiment 2-5 tested the efficacy of four additional extracts under similar conditions. Based on the results of Experiment 1, we tested these extracts in the 1-5 mg/kg dose-range, except for Extract No. V, which proved to have a very narrow effective dose range in preliminary studies. Therefore, the increment of doses was $0.5 \mathrm{mg} / \mathrm{kg}$ with this extract. The four extracts were tested in separate experiments. Sample size was 8-10 per group, except for Extract No V, where sample size was 16 per group.

Based on the results of Experiments 1-5, Extract No IV was selected for further analysis. In Experiment 6 and 7, we studied a wider dose range $(1-8 \mathrm{mg} / \mathrm{kg})$ in the elevated plus-maze, $30 \mathrm{~min}$ and $1 \mathrm{~h}$ after treatments, respectively. Sample size was 12 per group. The doses that proved most effective in Experiments 6 and 7 were also studied in the social interaction and shock-induced social avoidance tests (Experiments 8-9). Sample size was 12 
and 8 per group, respectively. Finally, locomotor effects were studied in the open-field test (Experiment 10). The doses tested were 2-16 mg/kg; sample size was $15-16$ per group.

The behavioral effects of the benzodiazepine chlordiazepoxide were also studied for comparison. In Experiment 11, we studied the effects of 1, 2, 3, 4, 6, 8, 10, 12, $14 \mathrm{mg} / \mathrm{kg}$ chlordiazepoxide in the elevated plus-maze, $30 \mathrm{~min}$ after treatment. This detailed doseresponse curve was taken as chlordiazepoxide was shown to have a biphasic effect on locomotion. Sample size was 10-14 per treatment group. Experiment 12 established the effects of chlordiazepoxide in the elevated plus-maze $1 \mathrm{~h}$ after treatments. The dose-range studied was 2-8 mg/kg, and included doses that increased and decreased locomotion in Experiment 11. Sample size was 10 per group. The effects of chlordiazepoxide in the social interaction and shock-induced social avoidance tests were investigated in Experiments 13 and 14. In the social interaction test, rats were given $1,2,5$, and $10 \mathrm{mg} / \mathrm{kg}$ chlordiazepoxide. Sample size was 12 per group. A specific dose-range was investigated in the shock-induced social avoidance test. Previous experience showed that this test is especially sensitive to the sedative effects of chlordiazepoxide. Therefore, rats were treated with $0.5,1,2.5$, and 5 $\mathrm{mg} / \mathrm{kg}$ in this test. Because both the anxiolytic and sedative effects of chlordiazepoxide were robust in earlier experiments, sample size was 7 in this experiment.

\section{Pharmacological treatment}

The following extracts were studied in the experiments: Echinacea purpurea root extract (EPO Istituto Farmacochimico Fitoterapico, Milano, Italy; batch No 0700326; extraction procedure: ethanol 4\% V/V; ratio herbal drug : drug preparation: 5-12:1; excipient: maize dextrin 30\%; marker: Echinacoside 4\%), Echinacea purpurea herb extract (Finzelberg GmbH and Co. KG, Andernach, Germany; Batch No. 07022307; extraction: ethanol $60 \% \mathrm{M} / \mathrm{M}$; ratio herbal drug : native extract: 4-10 : 1; excipients: maltodextrin $13 \%$ and colloidal silica anhydrate $2 \%$; marker: total phenols $4 \%$ ), and 
Echinacea angustifolia root extract (Euromed SA, Millet del Valles, Spain; Batch No. 419061; extraction: ethanol 85\% V/V; ratio herbal drug : native extract: 6.5-8 : 1; excipient: maltodextrin 30\%; marker: Echinacoside 4\%). All three extracts were dissolved in $0.4 \%$ methylcellulose in saline. We also studied a hydroalcoholic extract of Echinacea purpurea roots (FitoChem Ltd. Monor, Hungary; Batch No. FECH-010011205; extraction: ethanol 70\% V/V; ratio herbal drug : native extract: 4-8 : 1; excipient: none; marker: not standardized). Before experimental use, the ethanol was evaporated at $4{ }^{\circ} \mathrm{C}$, and the dry residue was dissolved in $0.4 \%$ methylcellulose in saline. Finally, we investigated an Echinacea angustifolia root extract prepared by the Department of Pharmacognosy, Faculty of Pharmacy, University of Szeged (Hungary). Briefly, $80 \mathrm{~g}$ air-dried and powdered root of Echinacea purpurea was extracted with $1 \times 300$ and $2 \times 200 \mathrm{ml} 70 \%$ EtOH using an ultrasonic extractor for 10-10 min. The filtered extracts were combined, concentrated and dissolved in $15 \mathrm{ml}$ water. The aqueous solution was lyophilized, yielding $8.67 \mathrm{~g}$ dark brown and semifluid extract. Before experimental use, it was physically dispersed, dissolved in small amounts of dimethyl sulphoxide (DMSO) and diluted to the final volume by $0.4 \%$ methylcellulose. The final concentration of DMSO was 3.3\% at each test concentration. Controls received a similar mixture of DMSO and methylcellulose. Chlordiazepoxide came from Sigma (Budapest, Hungary) and was dissolved in $0.4 \%$ methylcellulose in saline.

All treatments were administered per os in a volume of $2 \mathrm{ml} / \mathrm{kg}$. Controls received $0.4 \%$ methylcellulose except for the last mentioned extract (see above).

\section{Behavioral tests}

Behavioral studies were performed in the early hours of the dark (active) period between 1100 and $1300 \mathrm{~h}$. Each experiment was performed in several series balanced over groups. Group assignment was random. Behavior was video recorded and later analyzed by an experimenter blind to treatment conditions. 
The tests were performed as described earlier (Haller et al., 2000; Haller and Bakos, 2002; Haller et al., 2003; Leveleki et al., 2006). Briefly, the elevated plus-maze (arm length $50 \mathrm{~cm}$, arm width $15 \mathrm{~cm}$, wall height $30 \mathrm{~cm}$ and platform height $80 \mathrm{~cm}$ ) was illuminated by dim red light. Rats were placed into the center of the apparatus and were allowed to explore it for $5 \mathrm{~min}$. Closed-arm entries were considered indicators of locomotor activity, whereas open arm exploration (duration and \% entries) was used as a measure of anxiety (Pellow et al. 1985). The social interaction test arena was a plastic box of 40x60x60 $\mathrm{cm}$ that was lit by white light. Pairs of similarly treated rats were placed in the arena, and their behavior was recorded for $10 \mathrm{~min}$. Subjects were unfamiliar to each other. In this test, anxiety is shown by the duration of social interactions defined as sniffing movements directed towards the partner rat. Exploration/walking and resting are indicative of sedative or muscle-relaxant effects (File and Hyde, 1978; File and Johnston, 1989; Guy and Gardner, 1985). The social avoidance test was performed on two consecutive days. On the first day, rats were exposed to 10 electric shocks ( $3 \mathrm{~mA})$ over $5 \mathrm{~min}$ in a plastic box of $30 \times 30 \times 30 \mathrm{~cm}$. Controls were placed into the box, but received no shocks. On the next day, rats were studied in a three-compartment plastic cage. The subject was placed in the habituation compartment $(15 \times 40 \mathrm{~cm})$ that was separated from the rest of the cage by an opaque sliding door. After 3 min, the sliding door was removed and the rat was allowed to explore the test arena $(40 \mathrm{~cm} \mathrm{x} 40 \mathrm{~cm})$ for $5 \mathrm{~min}$. The third compartment contained a large unfamiliar male confined behind a transparent, perforated Plexiglas wall. In this test, anxiety is indicated by the number of entries into, and the time spent in the test arena i.e. in the vicinity of the unfamiliar opponent. Shock exposure strongly inhibits opponent visits, a response that is abolished by anxiolytics (Leveleki et al., 2006). The open-field was a circular area with a diameter of $90 \mathrm{~cm}$. Rats were placed next to the wall of the open-field and were allowed to explore the arena for $10 \mathrm{~min}$. The arena was 
divided into equal sub-areas by concentric and radial lines. Locomotor activity was shown by the number of line crossings.

\section{HPLC analysis}

HPLC analysis was carried out on a Waters instrument (Milford, MA, USA; solvent delivery system $6000 \mathrm{~A}$, pump $600 \mathrm{E}$, UV detector type 2487 , Rheodyne $7725 \mathrm{i}$ injector, Empower software). The alkamide profile was investigated at $25^{\circ} \mathrm{C}$ on LiChrospher RP-18 column (5 $\mu \mathrm{m}, 125-4 \mathrm{~mm}$, Merck) using linear gradient of acetonitrile-H2O 2:3 $\rightarrow 4: 1(0-30 \mathrm{~min})$ at flow of $1 \mathrm{ml} / \mathrm{min}$ detected at $254 \mathrm{~nm}$. Peak assignment was made according to Bauer and Remiger (1989).

\section{Statistical analysis}

Statistical analysis was made by the STATISTICA software (Tulsa, USA). Data were presented as means \pm the standard error of the mean (SEM). Significance level was set at $\mathbf{p}<\mathbf{0 . 0 5}$. Behavioral data were analyzed by Kruskall-Wallis ANOVA. MannWhitney post-hoc comparisons were also run where appropriate.

\section{Results}

Screening experiments

Extract No I significantly increased open arm exploration with marginal effects on locomotion as shown by closed arm entries (Table 1). However, only the 1.5 and $2 \mathrm{mg} / \mathrm{kg}$ doses were effective; neither 1 nor $3 \mathrm{mg} / \mathrm{kg}$ decreased anxiety in the elevated plus-maze. In addition, the time spent on the open arms was significantly increased, but open arm choice (\% open arm entries) showed non-significant variation only.

Extracts No II and III failed to affect behavior (Table 2). Extract No IV appeared to dose-dependently increase open arm exploration (Table 2). The effect was significant at the highest dose tested. Closed arm entries were not changed by the treatments. Extract No V 
increased the duration of open arm exploration at $1 \mathrm{mg} / \mathrm{kg}$ only; neither 0.5 nor $1.5 \mathrm{mg} / \mathrm{kg}$ were effective (Table 2). In addition, \% open arm entries showed no significant changes.

\section{Behavioral effects of Extract No IV}

The effects of extract No IV were investigated in the elevated plus-maze over a wider dose-range, both $30 \mathrm{~min}$ and $1 \mathrm{~h}$ after treatments (Fig. 1, upper panels). Locomotion as shown by closed arm entries were not affected at either time-point $(\mathrm{H}(7,120)=5.18 ; \mathrm{p}>0.5$, and $H(7,120)=7.01 ; p>0.4$, respectively). The duration of open arm entries increased at both time points $(30 \mathrm{~min}: \mathrm{H}(7,120)=22.96 ; \mathrm{p}<0.01)$; $1 \mathrm{~h}: \mathrm{H}(7,120)=19.65 ; \mathrm{p}<0.01)$. Open arm choice was affected significantly after $30 \min (H(7,120)=23.70 ; p<0.01)$ but not after $1 \mathrm{~h}$ $(H(7,120)=10.79 ; p=0.14)$. Post-hoc comparisons showed that the effective dose-range was 3-6 $\mathrm{mg} / \mathrm{kg}$ after $30 \mathrm{~min}$ and 4-8 $\mathrm{mg} / \mathrm{kg}$ after $1 \mathrm{~h}$.

In the social interaction test, resting, exploration and agonistic interactions showed nonsignificant changes $(\mathrm{H}(3,80)$ values were $1.59,3.79$, and $0.42 ; \mathrm{p}$ values were larger than 0.3 at least) (Fig. 1. lower left-hand panel). Social interactions were increased by both the 3 and 4 $\mathrm{mg} / \mathrm{kg}$ dose $(\mathrm{H}(3,80)=14.72, \mathrm{p}<0.001)$

In the shock-induced social avoidance model, the extract abolished social avoidance at 3 and $4 \mathrm{mg} / \mathrm{kg}(\mathrm{H}(6,80)=20.11 ; \mathrm{p}<0.005)$ (Fig. 1. lower middle panel). Locomotion was not affected by the extract within the $2-16 \mathrm{mg} / \mathrm{kg}$ dose range $(\mathrm{H}(4,79)=1.4 ; \mathrm{p}>0.8)($ Fig. 1. lower left-hand panel).

\section{The effects of chlordiazepoxide}

As expected, chlordiazepoxide significantly decreased anxiety-like behavior in the elevated plus-maze both $30 \mathrm{~min}$ and $1 \mathrm{~h}$ after treatments (\% open arm entries $30 \mathrm{~min}$ : $H(9,132)=29.27 ; p<0.005 ; \%$ open arm entries $1 \mathrm{~h}: H(4,60)=15.48 ; \mathrm{p}<0.005 ; \%$ time in open arm 30 min: $H(9,132)=H(9,132)=34.38 ; p<0.0001 ; \%$ time in open arm $1 \mathrm{~h}: H(4,60)$ $=19.63 ; \mathrm{p}<0.001)$ (Fig. 2, upper panels). However, the anxiolytic effects of chlordiazepoxide 
were not devoid of locomotor effects $(30 \mathrm{~min}: \mathrm{H}(9,132)=33.13 ; \mathrm{p}<0.0001 ; 1 \mathrm{~h}: \mathrm{H}(4,60)=$ 9.83; $\mathrm{p}<0.04)$. Post-hoc comparisons showed that 30 min after treatments, chlordiazepoxide increased locomotion at 2 and $3 \mathrm{mg} / \mathrm{kg}$, and decreased locomotion above $8 \mathrm{mg} / \mathrm{kg}$. The dose range within which chlordiazepoxide decreased anxiety without affecting locomotion was 4-6 $\mathrm{mg} / \mathrm{kg}$ at $30 \mathrm{~min}$, and $4 \mathrm{mg} / \mathrm{kg}$ at $1 \mathrm{~h}$.

Chlordiazepoxide significantly increased social interactions in the social interaction test $(H(4,72)=13.39 ; p<0.01)$ (Fig. 2, lower left hand panel). No locomotion-suppressing effects were noticed in this test, as neither resting, nor exploration were affected significantly $(H(4,72)=8.89 ; p<0.07$ and $H(4,72)=3.24 ; p>0.5)$. We note that the marginally significant difference in resting shown by the Kruskall-Wallis test was due to differences between chlordiazepoxide-treated groups (the lowest resting value was seen at chlordiazepoxide 2 $\mathrm{mg} / \mathrm{kg}$ ). In contrast to extract No. IV, chlordiazepoxide dramatically reduced agonistic interactions $(H(4,72)=29.60 ; p<0.0001)$. In the shock-induced social avoidance test, 0.5 and $1 \mathrm{mg} / \mathrm{kg}$ did, whereas 2.5 and $5 \mathrm{mg} / \mathrm{kg}$ did not abolish social avoidance $(\mathrm{H}(5,42)=31.89 ; \mathrm{p}<$ 0.0001) (Fig. 2. lower right-hand panel). The failure of higher doses to abolish social avoidance was likely due to sedation, as opponent entries were reduced from $5.14 \pm 0.70$ at 1 $\mathrm{mg} / \mathrm{kg}$ chlordiazepoxide to $2.29 \pm 0.57$ and $1.14 \pm 0.55$ at $2.5 \mathrm{mg} / \mathrm{kg}$ and $5 \mathrm{mg} / \mathrm{kg}$

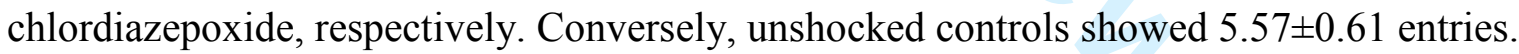

\section{HPLC measurements}

The results of HPLC measurements were summarized in Fig. 3. Two of the extracts (No. 2 and No. 3), contained very low amounts of alkamides (Fig. 3 upper right hand panel). Alkamides were not lacking in these extracts (see the insert of Fig. 3 upper right hand panel), but their absorption curves became almost flat when the scale of the absorption curve was set such to accommodate the high levels seen in other extracts. Alkamide contents were considerably higher in Extracts No 1, 4, and 5. The level of 


\section{these compounds and, more importantly their fingerprint showed considerable differences in these extracts.}

\section{Discussion}

Out of the five Echinacea extracts studied, three affected anxiety-like behavior. Two of these, however, had a very narrow dose range, encompassing no more than $0.5 \mathrm{mg} / \mathrm{kg}$. Neither lower nor higher doses proved effective. There was only one extract that robustly decreased anxiety in three different tests, with an effective dose-range that was comparable with that of chlordiazepoxide. Locomotion was not affected by this extract at doses that were 5 times larger than the minimally effective anxiolytic dose. Chlordiazepoxide robustly decreased anxiety-like behavior but also suppressed locomotion.

The anxiolytic effects of chlordiazepoxide were consistent with those reported earlier in the same tests (File and Hyde, 1978; Leveleki et al., 2006; Patel and Malick, 1982; Pellow et al., 1982; Treit et al., 1981). Locomotor effects were also similar to those reported earlier; low doses (e.g. 2-3 mg/kg) increased, whereas larger doses (e.g. 5-10 mg/kg) suppressed locomotion (Davies and Steinberg, 1984; File and Pellow, 1985; Fernandes and File, 1999; Martin et al., 1982; McElroy et al., 1982). Also consistent with earlier findings, locomotor stimulation that was seen at 30 min disappeared when effects were tested $1 \mathrm{~h}$ after injections (Davies and Steinberg, 1984).

To our knowledge, this is the first study showing that Echinacea preparations posses an anxiolytic potential. Unfortunately, however, this potential is not common, as only three out of five preparations showed any anxiolytic effect. In addition, the effective dose range was very narrow $(0.5 \mathrm{mg} / \mathrm{kg})$ in the case of two effective extracts. Noteworthy, very narrow dose ranges are irrelevant from a therapeutic perspective as such data are difficult to extrapolate to effective doses in humans. In addition, a very narrow dose-range involves the establishment of precise weight-dependent dosage regimens, which appears unrealistic in a clinical setting. 
Extract No. 4, however, decreased anxiety at a low dose and over a wide, bell-shaped doseresponse curve that was comparable with that of chlordiazepoxide. Such bell-shaped doseresponse curves are commonly seen with herbal extracts (Butterweck et al., 1997). Moreover, this phenomenon $\square$ also called hormesis $\square$ appears to be a general feature of drug effects (Calabrese and Baldwin, 2001, Calabrese, 2008).

Discrepant findings with different extracts are likely explained by the fact that while the main constituents of various Echinacea species are essentially similar, the absolute amounts and the quantitative relationships between different constituents are subject to major variation (Kapteyn et al., 2002; Pellati et al., 2005; Percival, 2000; Perry et al., 2001; Wu et al., 2009). Noteworthy, the immunostimulant effect of Echinacea preparations also show extreme variations (Tamta et al., 2008). We hypothesized that Echinacea preparations affect anxiety-related behaviors mainly due to their alkamide content (see Introduction). This hypothesis was partly supported by HPLC findings, as the extracts that contained the lowest amounts of alkamides were behaviorally inactive. Efficacy, however, was not directly related to alkamide content. Extract No 5 contained high amounts of alkamides but had modest behavioral effects, while Extract No 4 strongly decreased anxiety despite its relatively lower alkamide content. One can hypothesize that behavioral effects depend partly on the total amount, partly on the fingerprint of the different alkamides. As such, behavioral effects may develop in conjunction with the additive/synergistic and possibly antagonistic effects of various alkamides. The involvement of other components cannot be ruled out either. Further research is required to elucidate the compositions that differentiate efficient and inefficient preparations.

The perceived or real risks of conventional drug treatments -as well as personal beliefs about healthy lifestyles- lead to a strong demand for alternative therapies among both patients and medical practitioners (Astin, 1998; Barrett et al., 2003; Ben-Arye et 
al., 2008; Dilhuydy, 2003). Such alternative therapies would be welcome provided that the treatment is safe and its efficacy is proven. Among herbs, anxiolytic effects are not unique to Echinacea. Effective doses, however, are rather high in most cases (Albizzia julibrissin: $100-200 \mathrm{mg} / \mathrm{kg}$ in the rat plus-maze, Kim et al., 2004; Centella asiatica: 500 $\mathrm{mg} / \mathrm{kg}$ in the rat plus-maze, Wijeweera et al., 2006; Eschsholzia californica: $25 \mathrm{mg} / \mathrm{kg}$ in the mouse light/dark test, Rolland et al., 1991; Hypericum perforatum: 100-200 mg/kg in the mouse T-maze, Flausino et al., 2002; Passiflora species: $300-800 \mathrm{mg} / \mathrm{kg}$ in the rats plus-maze, Reginatto et al., 2006; Valeriana officinalis: above $100 \mathrm{mg} / \mathrm{kg}$, various tests, Oliva et al., 2004). In other cases, the effective dose-range was as narrow as with our Extracts No. 1 and 5 (Hasenohrl et al., 1998). More promising effects were obtained with kava kava (Piper mysticum) that proved to be clinically effective (Pittler and Ernst, 2003). Later research, however, revealed that this plant has major side effects (Christl et al., 2009; Teschke et al., 2008).

Evidence accumulated over many decades demonstrates that Echinacea preparations have an excellent safety profile (Barnes et al., 2005; Birt et al., 2008; Blumenthal and Busse, 1998; Borchers et al., 2000; Izzo and Ernst, 2001; Tesch, 2003). In addition, the doses that showed anxiolytic effects in the present study (3-7 mg/kg) were about one order of magnitude lower than those that were efficient in laboratory models of traditional indications (30-130 mg/kg; Abouelella et al., 2007; Zhai et al., 2007). This comparison suggests that human anxiolytic doses would be similarly low, which further decreases the risks associated with the potential use of Echinacea preparations for the treatment of anxiety. Taken together, these considerations suggest that from the point of view of safety, Echinacea preparations are excellent candidates for the alternative treatment of anxiety. On the other hand, the remarkable anxiolytic effects demonstrated here suggest that certain Echinacea preparations are excellent alternative anxiolytics from the point of view of efficacy as well. 


\section{References}

Abouelella AM, Shahein YE, Tawfik SS, Zahran AM. 2007. Phytotherapeutic effects of Echinacea purpurea in gamma-irradiated mice. J Vet Sci 8: 341-351.

Astin JA. 1998. Why patients use alternative medicine: results of a national study. JAMA 279: 1548-1553.

Barnes J, Anderson LA, Gibbons S, Phillipson JD. 2005. Echinacea species (Echinacea angustifolia (DC.) Hell., Echinacea pallida (Nutt.) Nutt.,Echinacea purpurea (L.) Moench): a review of their chemistry, pharmacology and clinical properties. J Pharm Pharmacol 57: 929-954.

Barrett B, Marchand L, Scheder J, Plane MB, Maberry R, Appelbaum D, Rakel D, Rabago D. 2003. Themes of holism, empowerment, access, and legitimacy define complementary, alternative, and integrative medicine in relation to conventional biomedicine. J Altern Complement Med 9: 937-947.

Bauer R, Remiger P. 1989. TLC and HPLC Analysis of Alkamides in Echinacea Drugs. Planta Med 55: 367-371.

Ben-Arye E, Frenkel M, Klein A, Scharf M. 2008. Attitudes toward integration of complementary and alternative medicine in primary care: perspectives of patients, physicians and complementary practitioners. Patient Educ Couns 70: 395-402.

Biber A, Franck-Karl G, Waimer F, Riegert U, Wiget R. 2009. Analytical characterisation of homoeopathic mother tinctures. Pharmeur Sci Notes 2009(1):1-4.

Birt DF, Widrlechner MP, Lalone CA, Wu L, Bae J, Solco AK, Kraus GA, Murphy PA, Wurtele ES, Leng Q, Hebert SC, Maury WJ, Price JP. 2008. Echinacea in infection. Am J Clin Nutr 87: 488S-492S.

Blumenthal M, Busse WR. 1998. The complete German Commission E monographs, Therapeutic guide to herbal medicines. Austin, Texas American Botanical Council: Boston.

Borchers AT, Keen CL, Stern JS, Gershwin ME. 2000. Inflammation and Native American medicine: the role of botanicals. Am J Clin Nutr 72: 339-347.

Butterweck V, Wall A, Liefländer-Wulf U, Winterhoff H, Nahrstedt A. 1997. Effects of the total extract and fractions of Hypericum perforatum in animal assays for antidepressant activity. Pharmacopsychiatry 30 Suppl 2:117-124.

Calabrese EJ, Baldwin LA. 2001. U-shaped dose-responses in biology, toxicology, and public health. Annu Rev Public Health 22:15-33.

Calabrese EJ. 2008. Hormesis and medicine. Br J Clin Pharmacol 66: 594-617. 
Christl SU, Seifert A, Seeler D. 2009. Toxic hepatitis after consumption of traditional kava preparation. J Travel Med 16: 55-56.

Davies C, Steinberg H. 1984. A biphasic effect of chlordiazepoxide on animal locomotor activity. Neurosci Lett 46: 347-351.

Dilhuydy JM. 2003. Patients' attraction to complementary and alternative medicine (CAM): a reality which physicians can neither ignore nor deny. Bull Cancer 90: 623-628.

Fernandes C, File SE. 1999. Dizocilpine does not prevent the development of tolerance to the anxiolytic effects of diazepam in rats. Brain Res 815: 431-434.

File SE, Cheeta S, Akanezi C. 2001. Diazepam and nicotine increase social interaction in gerbils: a test for anxiolytic action. Brain Res 888: 311-313.

File SE, Hyde JRG. 1978. Can social interaction be used to measure anxiety? $\mathrm{Br} J$ Pharmacol 62: 19-24.

File SE, Johnston AL. 1989. Lack of effects of 5HT3 receptor antagonists in the social interaction and elevated plus-maze tests of anxiety in the rat. Psychopharmacology 99: 248251.

File SE, Pellow S. 1985. The effects of triazolobenzodiazepines in two animal tests of anxiety and in the holeboard. Br J Pharmacol 86: 729-735.

Flausino OA Jr, Zangrossi H Jr, Salgado JV, Viana MB. 2002. Effects of acute and chronic treatment with Hypericum perforatum L. (LI 160) on different anxiety-related responses in rats. Pharmacol Biochem Behav 71: 251-257.

Freund TF. 2003. Interneuron Diversity series: Rhythm and mood in perisomatic inhibition. Trends Neurosci 26: 489-495.

Guy AP, Gardner CR. 1985. Pharmacological characterization of a modified social interaction model of anxiety in the rat. Neuropsychobiology 13, 194-200.

Haller J, Bakos N. 2002. Stress-induced social avoidance: a new model of stressinduced anxiety? Physiol Behav 77: 327-332.

Haller J, Halász J, Makara GB. 2000. Housing conditions and the anxiolytic efficacy of buspirone: the relationship between main and side effects. Behav Pharmacol 11: 403-412.

Haller J, Leveleki C, Baranyi J, Mikics E, Bakos N. 2003. Stress, social avoidance and anxiolytics: a potential model of stress-induced anxiety. Behav Pharmacol 14: 439-446.

Haller J, Varga B, Ledent C, Freund TF. 2004. CB1 cannabinoid receptors mediate anxiolytic effects: convergent genetic and pharmacological evidence with CB1-specific agents. Behav Pharmacol 15: 299-304. 
Hasenohrl RU, Topic B, Frisch C, Häcker R, Mattern CM, Huston JP. 1998.

Dissociation between anxiolytic and hypomnestic effects for combined extracts of zingiber officinale and ginkgo biloba, as opposed to diazepam. Pharmacol Biochem Behav 59: 527535.

Izzo AA, Ernst E. 2001. Interactions between herbal medicines and prescribed drugs: a systematic review. Drugs 61: 2163-2175.

Kapteyn J, Goldsbrough B, Simon E. 2002. Genetic relationships and diversity of commercially relevant Echinacea species. Theor Appl Genet 105: 369-376.

Kim WK, Jung JW, Ahn NY, Oh HR, Lee BK, Oh JK, Cheong JH, Chun HS, Ryu JH. 2004. Anxiolytic-like effects of extracts from Albizzia julibrissin bark in the elevated plusmaze in rats. Life Sci 75: 2787-2795.

Konishi Y, Hitomi Y, Yoshida M, Yoshioka E. 2005. Pharmacokinetic study of caffeic and rosmarinic acids in rats after oral administration. J Agric Food Chem 53: 4740-4746.

Leveleki C, Sziray N, Levay G, Barsvari B, Soproni K, Mikics E, Haller J. 2006. Pharmacological evaluation of the stress-induced social avoidance model of anxiety. Brain Res Bull 69: 153-160.

Martin JR, Oettinger R, Driscoll P, Buzzi R, Bättig K. 1982. Effects of chlordiazepoxide and imipramine on maze patrolling within two different maze configurations by psychogenetically selected lines of rats. Psychopharmacology 78: 58-62.

Mazzola C, Medalie J, Scherma M, Panlilio LV, Solinas M, Tanda G, Drago F, Cadet JL, Goldberg SR, Yasar S. 2009. Fatty acid amide hydrolase (FAAH) inhibition enhances memory acquisition through activation of PPAR-alpha nuclear receptors. Learn Mem 16: 332-337.

McElroy JF, Fleming RL, Feldman RS. 1985. A comparison between chlordiazepoxide and CL 218,872--a synthetic nonbenzodiazepine ligand for benzodiazepine receptors on spontaneous locomotor activity in rats. Psychopharmacology 85: 224-226.

Melchart D, Linde K, Worku F, Sarkady L, Holzmann M, Jurcic K, Wagner H. 1995. Results of five randomized studies on the immunomodulatory activity of preparations of Echinacea. J Altern Complement Med 1: 145-160.

Oliva I, Gonzalez-Trujano ME, Arrieta J, Enciso-Rodriguez R, Navarrete A. 2004. Neuropharmacological profile of hydroalcohol extract of Valeriana edulis ssp. procera roots in mice. Phytother Res 18: 290-296.

Patel JB, Malick JB. 1982. Pharmacological properties of tracazolate: a new nonbenzodiazepine anxiolytic agent. Eur J Pharmacol 78: 323-333. 
Pellati F, Benvenuti S, Melegari M, Lasseigne T. 2005. Variability in the composition of anti-oxidant compounds in Echinacea species by HPLC. Phytochem Anal 16: 77-85.

Pellow S, Chopin P, File SE, Briley M. 1985. Validation of open: closed arm entries in an elevated plus-maze as a measure of anxiety in the rat. J Neurosci Methods 14: 149-167.

Percival SS. 2000. Use of Echinacea in medicine. Biochem Pharm 60:155-158.

Pereira P, Tysca D, Oliveira P, da Silva Brum LF, Picada JN, Ardenghi P. 2005. Neurobehavioral and genotoxic aspects of rosmarinic acid. Pharmacol Res 52: 199-203.

Perry NB, Burgess EJ, Glennie VL. 2001. Echinacea standardization: analytical methods for phenolic compounds and typical levels in medicinal species. J Agric Food Chem 49: 1702-1706.

Piomelli D, Tarzia G, Duranti A, Tontini A, Mor M, Compton TR, Dasse O, Monaghan EP, Parrott JA, Putman D. 2006. Pharmacological profile of the selective FAAH inhibitor KDS-4103 (URB597). CNS Drug Rev 12: 21-38.

Pittler MH, Ernst E. 2003. Kava extract for treating anxiety. Cochrane Database Syst $\operatorname{Rev}(1): \mathrm{CD} 003383$.

Reginatto FH, De-Paris F, Petry RD, Quevedo J, Ortega GG, Gosmann G, Schenkel EP. 2006. Evaluation of anxiolytic activity of spray dried powders of two South Brazilian Passiflora species. Phytother Res 20: 348-351.

Rolland A, Fleurentin J, Lanhers MC, Younos C, Misslin R, Mortier F, Pelt JM. 1991. Behavioural effects of the American traditional plant Eschscholzia californica: sedative and anxiolytic properties. Planta Med 57: 212-216.

Starowicz K, Cristino L, Di Marzo V. 2008. TRPV1 receptors in the central nervous system: potential for previously unforeseen therapeutic applications. Curr Pharm Des 14: 4254.

Takeda H, Tsuji M, Miyamoto J, Masuya J, Iimori M, Matsumiya T. 2003. Caffeic acid produces antidepressive- and/or anxiolytic-like effects through indirect modulation of the alpha 1A-adrenoceptor system in mice. Neuroreport 14: 1067-1070.

Tamta H, Pugh ND, Balachandran P, Moraes R, Sumiyanto J, Pasco DS. 2008. Variability in in vitro macrophage activation by commercially diverse bulk echinacea plant material is predominantly due to bacterial lipoproteins and lipopolysaccharides. J Agric Food Chem 56: 10552-10556.

Tesch BJ. 2003. Herbs commonly used by women: an evidence-based review. Am J Obstet Gynecol 188: S44-S55. 
Teschke R, Schwarzenboeck A, Hennermann KH. 2008. Kava hepatotoxicity: a clinical survey and critical analysis of 26 suspected cases. Eur J Gastroenterol Hepatol 20: 11821193.

Treit D, Pinel JP, Fibiger HC. 1981. Conditioned defensive burying: a new paradigm for the study of anxiolytic agents. Pharmacol Biochem Behav 15: 619-626.

Wijeweera P, Arnason JT, Koszycki D, Merali Z. 2006. Evaluation of anxiolytic properties of Gotukola (Centella asiatica) extracts and asiaticoside in rat behavioral models. Phytomedicine 13: 668-676.

Witkin JM, Tzavara ET, Nomikos GG. 2005. A role for cannabinoid CB1 receptors in mood and anxiety disorders. Behav Pharmacol 16: 315-331.

Woelkart K, Frye RF, Derendorf H, Bauer R, Butterweck V. 2009. Pharmacokinetics and Tissue Distribution of Dodeca-2E,4E,8E,10E/Z-tetraenoic Acid Isobutylamides after Oral Administration in Rats. Planta Med Apr 27. [Epub ahead of print] DOI: 10.1055/s-00291185631.

Woelkart K, Xu W, Pei Y, Makriyannis A, Picone RP, Bauer R. 2005. The endocannabinoid system as a target for alkamides from Echinacea angustifolia roots. Planta Med.; 71:701-705.

Wu L, Dixon PM, Nikolau BJ, Kraus GA, Widrlechner MP, Wurtele ES. 2009. Metabolic profiling of echinacea genotypes and a test of alternative taxonomic treatments. Planta Med.; 75:178-183.

Zhai Z, Liu Y, Wu L, Senchina DS, Wurtele ES, Murphy PA, Kohut ML, Cunnick JE. 2007. Enhancement of innate and adaptive immune functions by multiple Echinacea species. J Med Food.; 10:423-434. 
Table 1. The effects of extract No I in the elevated plus-maze.

\begin{tabular}{|l|c|c|c|}
\hline Group & $\begin{array}{c}\text { Closed entries } \\
\pm \text { SEM }\end{array}$ & $\begin{array}{c}\text { \% open entries } \\
\pm \text { SEM }\end{array}$ & $\begin{array}{c}\text { \% time in open arm } \\
\pm \text { SEM }\end{array}$ \\
\hline vehicle & 7,40 & 28,18 & 9,53 \\
& $\pm 0,61$ & $\pm 2,04$ & $\pm 1,44$ \\
\hline \multirow{2}{*}{$E_{l} 0.05 \mathrm{mg} / \mathrm{kg}$} & 7,30 & 32,59 & 12,17 \\
& $\pm 0,63$ & $\pm 3,26$ & $\pm 1,78$ \\
\hline \multirow{2}{*}{$E_{l} 1 \mathrm{mg} / \mathrm{kg}$} & 8,80 & 27,17 & 12,42 \\
& $\pm 1,16$ & $\pm 2,21$ & $\pm 2,33$ \\
\hline \multirow{2}{*}{$1.5 \mathrm{mg} / \mathrm{kg}$} & 8,67 & 37,62 & $\mathbf{2 1 , 4 1}$ \\
& $\pm 0,53$ & $\pm 2,08$ & $\pm 4,30$ \\
\hline \multirow{2}{*}{$E_{l} 2 \mathrm{mg} / \mathrm{kg}$} & 8,30 & 33,33 & $\mathbf{1 7 , 0 9}$ \\
& $\pm 0,91$ & $\pm 3,14$ & $\pm 1,99$ \\
\hline \multirow{2}{*}{$E_{l} 3 \mathrm{mg} / \mathrm{kg}$} & $10,80^{+}$ & 30,20 & 12,23 \\
& $\pm 0,80$ & $\pm 4,36$ & $\pm 3,32$ \\
\hline \multirow{2}{*}{$6 \mathrm{mg} / \mathrm{kg}$} & 9,30 & 27,43 & $\mathbf{1 0 , 9 1}$ \\
\hline$H(6,80)$ & $\pm 0,68$ & $\pm 1,83$ & 16,10 \\
\hline$p$ & 12,83 & 10,62 & 0,01 \\
\hline
\end{tabular}

$E_{I}$, extract No. I; H, Kruskall-Wallis coefficient; Post hoc comparisons:*, significantly different from control (bolded); ${ }^{+}$, marginal difference from control (italicized). 
Table 2. The effect of Extracts No II-V in the elevated plus-maze.

\begin{tabular}{|c|c|c|c|}
\hline Treatment & $\begin{array}{c}\text { Closed entries } \\
\pm \text { SEM }\end{array}$ & $\begin{array}{c}\text { \% open entries } \\
\text { 土SEM }\end{array}$ & $\begin{array}{c}\text { \%time in open arm } \\
\pm \text { SEM }\end{array}$ \\
\hline Control & $\begin{array}{c}6.72 \\
\pm 0.91 \\
\end{array}$ & $\begin{array}{l}21.46 \\
\pm 4.15\end{array}$ & $\begin{array}{c}6.07 \\
\pm 1.36 \\
\end{array}$ \\
\hline$E_{\| l} 1 \mathrm{mg} / \mathrm{kg}$ & $\begin{array}{r}7.75 \\
\pm 1.28 \\
\end{array}$ & $\begin{array}{l}19.03 \\
\pm 4.95\end{array}$ & $\begin{array}{r}6.53 \\
\pm 2.67 \\
\end{array}$ \\
\hline$E_{/ /} 3 \mathrm{mg} / \mathrm{kg}$ & $\begin{array}{r}6.80 \\
\pm 1.25\end{array}$ & $\begin{array}{l}18.75 \\
\pm 7.89\end{array}$ & $\begin{array}{r}3.08 \\
\pm 1.01\end{array}$ \\
\hline$E_{l l} 4 m g / k g$ & $\begin{array}{r}5.90 \\
\pm 1.03 \\
\end{array}$ & $\begin{array}{l}19.19 \\
\pm 5.56 \\
\end{array}$ & $\begin{array}{r}5.43 \\
\pm 2.15 \\
\end{array}$ \\
\hline$E_{l /} 5 m g / k g$ & $\begin{array}{r}7.00 \\
\pm 1.02 \\
\end{array}$ & $\begin{array}{l}22.76 \\
\pm 5.49\end{array}$ & $\begin{array}{r}8.92 \\
\pm 3.18 \\
\end{array}$ \\
\hline$H(4,56)$ & 1.82 & 1.23 & 2.11 \\
\hline$p$ & 0.8 & 0.9 & 0.7 \\
\hline control & $\begin{array}{l}7.50 \\
\pm 0.78 \\
\end{array}$ & $\begin{array}{l}24.69 \\
\pm 2.67 \\
\end{array}$ & $\begin{array}{l}7.58 \\
\pm 1.29\end{array}$ \\
\hline$E_{I I I} 1 \mathrm{mg} / \mathrm{kg}$ & $\begin{array}{r}8.00 \\
\pm 0.89\end{array}$ & $\begin{array}{l}29.88 \\
\pm 4.67\end{array}$ & $\begin{array}{l}13.38 \\
\pm 3.12\end{array}$ \\
\hline$E_{I I I} 2 \mathrm{mg} / \mathrm{kg}$ & $\begin{array}{r}5.92 \\
\pm 1.43\end{array}$ & $\begin{array}{l}26.34 \\
\pm 8.52\end{array}$ & $\begin{array}{r}4.81 \\
+1.25\end{array}$ \\
\hline$E_{I I I} 3 \mathrm{mg} / \mathrm{kg}$ & $\begin{array}{l}8.20 \\
\pm 0.63 \\
\end{array}$ & $\begin{array}{l}23.19 \\
\pm 3.73 \\
\end{array}$ & $\begin{array}{l}10.08 \\
\pm 2.65\end{array}$ \\
\hline$E_{I I I} 4 \mathrm{mg} / \mathrm{kg}$ & $\begin{array}{r}7.89 \\
\pm 1.03 \\
\end{array}$ & $\begin{array}{l}23.58 \\
\pm 5.09 \\
\end{array}$ & $\begin{array}{r}8.26 \\
\pm 3.38 \\
\end{array}$ \\
\hline$H(4,55)$ & 2.10 & 3.55 & 6.26 \\
\hline$p$ & 0.7 & 0.5 & 0.2 \\
\hline control & $\begin{array}{l}7.33 \\
\pm 0.71 \\
\end{array}$ & $\begin{array}{l}11.24 \\
\pm 3.35\end{array}$ & $\begin{array}{l}2.18 \\
\pm 0.57 \\
\end{array}$ \\
\hline$E_{I V} 1 \mathrm{mg} / \mathrm{kg}$ & $\begin{array}{c}7.92 \\
\pm 0.92\end{array}$ & $\begin{array}{r}8.46 \\
\pm 3.57\end{array}$ & $\begin{array}{r}2.37 \\
\pm 1.30\end{array}$ \\
\hline$E_{I V} 2 \mathrm{mg} / \mathrm{kg}$ & $\begin{array}{r}6.50 \\
\pm 1.10\end{array}$ & $\begin{array}{l}10.00 \\
\pm 3.22\end{array}$ & $\begin{array}{l}2.67 \\
\pm 0.84\end{array}$ \\
\hline$E_{I V} 3 \mathrm{mg} / \mathrm{kg}$ & $\begin{array}{c}7.92 \\
\pm 0.92 \\
\end{array}$ & $\begin{array}{l}18.54 \\
\pm 4.38\end{array}$ & $\begin{array}{l}6.93^{+} \\
\pm 2.08\end{array}$ \\
\hline$E_{I V} 4 \mathrm{mg} / \mathrm{kg}$ & $\begin{array}{r}7.75 \\
\pm 0.73 \\
\end{array}$ & $\begin{array}{c}23.93 \\
\pm 4.12\end{array}$ & $\begin{array}{c}10.43^{*} \\
\pm 3.49\end{array}$ \\
\hline$H(4,60)$ & 2.36 & 10.32 & 10.54 \\
\hline$p<$ & 0.7 & 0.04 & 0.03 \\
\hline Control & $\begin{array}{l}8,94 \\
\pm 0,82 \\
\end{array}$ & $\begin{array}{l}32,85 \\
\pm 3,93 \\
\end{array}$ & $\begin{array}{r}18,69 \\
\pm 3,43 \\
\end{array}$ \\
\hline$E_{V} 0.5 \mathrm{mg} / \mathrm{kg}$ & $\begin{array}{r}8,00 \\
\pm 0,85 \\
\end{array}$ & $\begin{array}{l}34,94 \\
\pm 4,84\end{array}$ & $\begin{array}{l}18,64 \\
\pm 4,43 \\
\end{array}$ \\
\hline$E_{V} 1 \mathrm{mg} / \mathrm{kg}$ & $\begin{array}{r}9,00 \\
\pm 0,87\end{array}$ & $\begin{array}{l}41,97 \\
\pm 4,70\end{array}$ & $\begin{array}{c}35,18^{*} \\
\pm 5,72\end{array}$ \\
\hline$E_{V} 1.5 \mathrm{mg} / \mathrm{kg}$ & $\begin{array}{r}9,56 \\
\pm 0,81\end{array}$ & $\begin{array}{l}40,47 \\
\pm 2,66 \\
\end{array}$ & $\begin{array}{l}27,66 \\
\pm 3,46 \\
\end{array}$ \\
\hline$E_{V} 2 \mathrm{mg} / \mathrm{kg}$ & $\begin{array}{r}8,63 \\
\pm 1,04 \\
\end{array}$ & $\begin{array}{l}37,63 \\
\pm 3,25 \\
\end{array}$ & $\begin{array}{l}25,81 \\
\pm 3,90 \\
\end{array}$ \\
\hline$H(4,80)$ & 1,65 & 3,16 & 9,42 \\
\hline$p$ & 0,80 & 0,50 & 0,05 \\
\hline
\end{tabular}

$E_{I-V}$, extract No. I-V; H, Kruskall-Wallis coefficient; Post hoc comparisons:*, significantly different from control (bolded); ${ }^{+}$, marginal difference from control (italicized). 


\section{Legend for figures}

Fig. 1. The effects of extract No 4 on anxiety-like behaviors and locomotion. E-IV, the Echinacea extract that showed promising anxiolytic effects in the screening experiments (see Table 2); *, significantly different from control in post-hoc comparisons $(\mathrm{p}<0.05$ at least $){ }^{+}$, marginally different from control $(0.1>\mathrm{p}>0.05)$.

Fig. 2. The effects of chlordiazepoxide in three anxiety tests. CDP, chlordiazepoxide; *, significantly different from control in post-hoc comparisons $(\mathrm{p}<0.05$ at least $) ;{ }^{+}$, marginally different from control $(0.1>p>0.05)$.

Fig. 3. HPLC chromatograms of the 5 extracts tested. The insert (upper right hand chromatogram) shows that Extracts No. 2 and 3 did not lack alkamides, but this is not visible at $\mathrm{Y}$-axis scales appropriate to accommodate the much higher levels seen in the other three extracts. 1, undeca-2E,4Z-diene-8,10-diynoic acid isobutylamide; 2, undeca-2Z,4E-diene8,10-diynoic acid isobutylamide; $\mathbf{3}$, dodeca-2E,4Z-diene-8,10-diynoic acid isobutylamide; $\mathbf{4}$, undeca-2E,4Z-diene-8,10-diynoic acid 2-methybutylamide; 5, dodeca-2E,4Z,10E-triene-8ynoic acid isobutylamide, 6, trideca-2E,7Z-diene-10,12-diinsav isobutylamide; 7, dodeca2E,4Z-diene-8,10-diynoic acid 2-methylbutylamide; 8, dodeca-2E,4E,8Z,10E-tetraenoic acid isobutylamide; 9, dodeca-2E,4E,8Z,10Z-tetraenoic acid isobutylamide; 11, dodeca-2E,4Edienoic acid; 18, pentadeca-2E,9Z-diene-12,14-diynoic acid isobutylamide. 
Figure 1

$275 \times 190 \mathrm{~mm}(96 \times 96 \mathrm{DPI})$

Haller et al., Figure 1
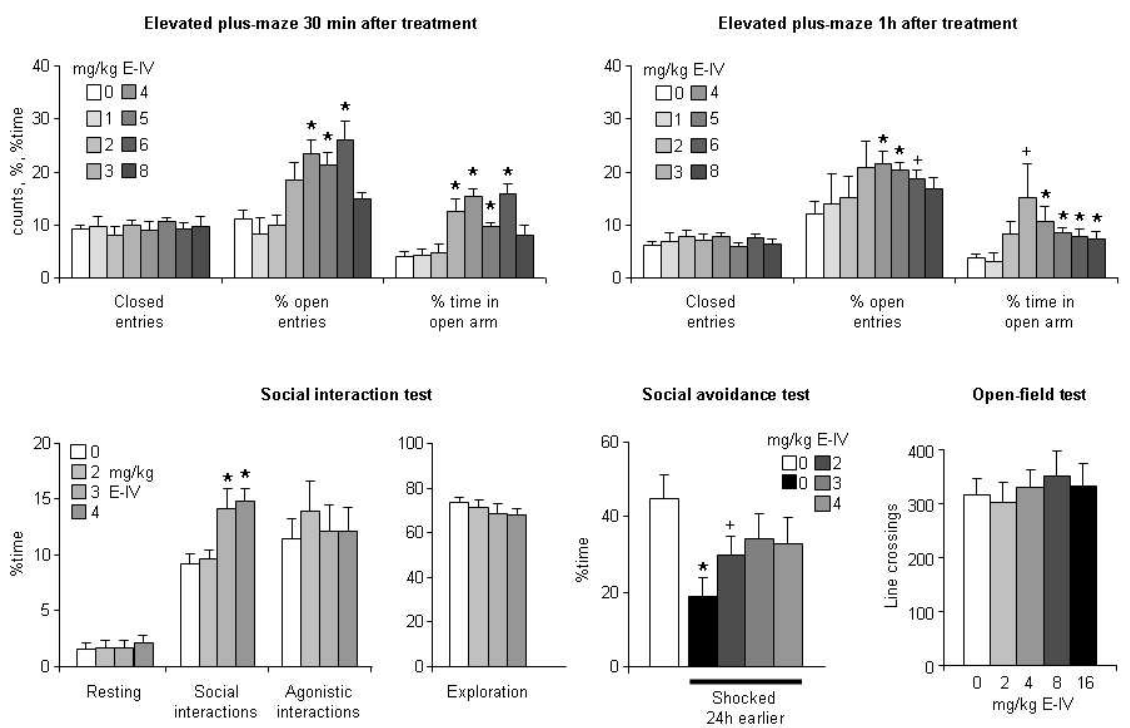
Haller et al., Figure 2

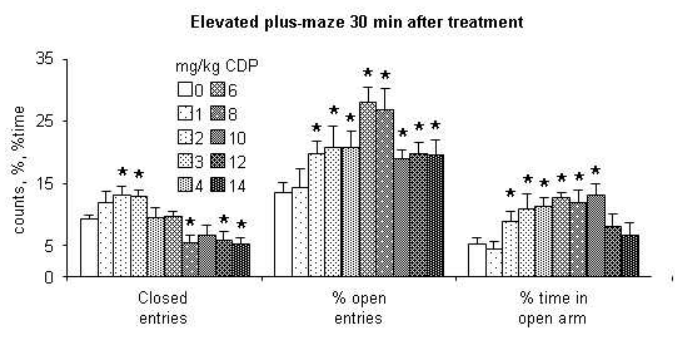
Elevated plus-maze $1 \mathrm{~h}$ after treatment
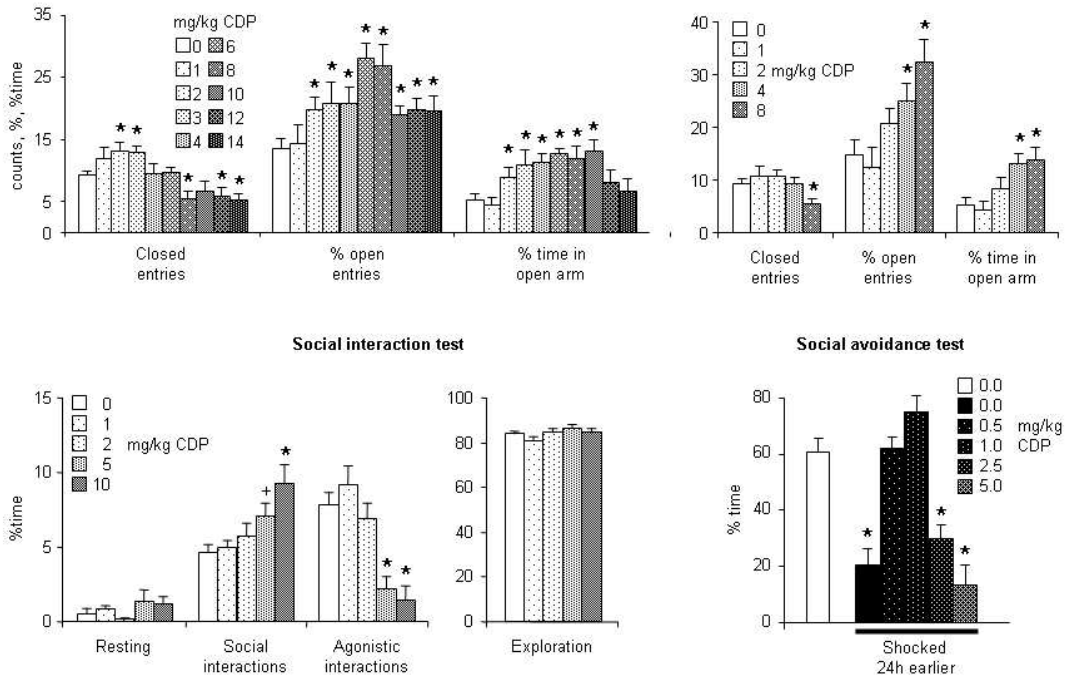

Figure 2

$275 \times 190 \mathrm{~mm}(96 \times 96$ DPI)

35

36

37

38

39

40

41

42

43

44

45

46

47

48

49

50

51

52

53

54

55

56

57 


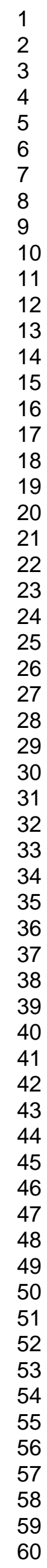
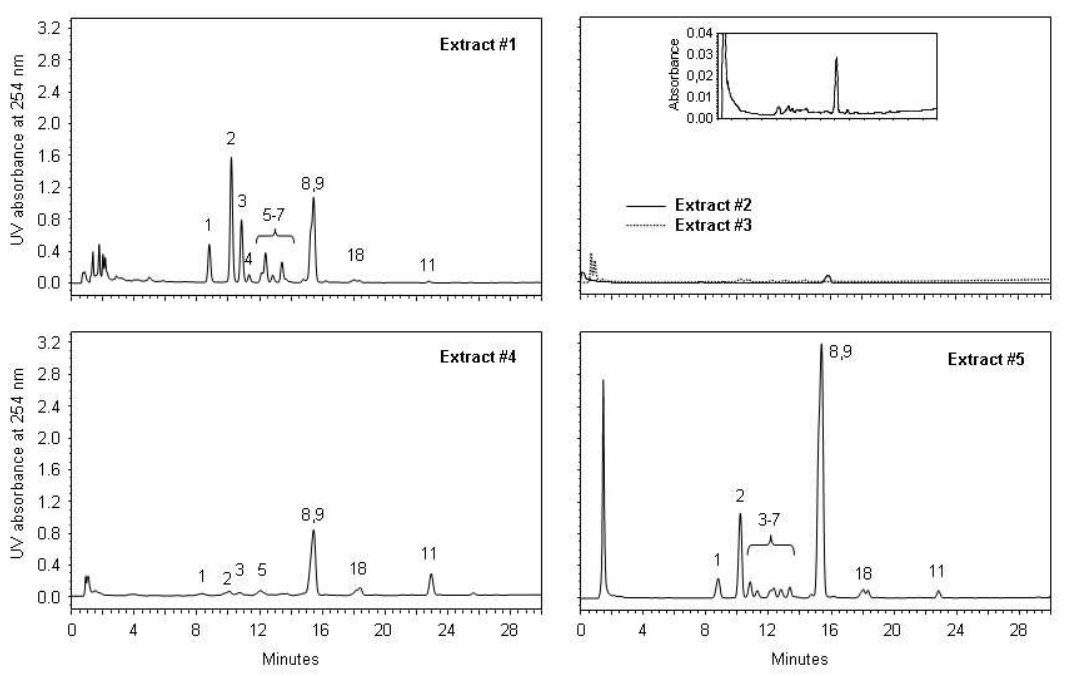

$275 \times 190 \mathrm{~mm}(96 \times 96 \mathrm{DPI})$ 